\title{
Günah Vergilerinin Şiddet Olayları Üzerindeki Etkisi
}

\author{
Abdülkerim EROĞLU* ${ }^{*}$ Haluk EGELiं ${ }^{* *}$ \\ ÖZ
}

Eski tarihlerde devlet yöneticileri günah olarak kabul edilen bir takım mal ve hizmetlerin tüketimini yasaklamaya gitmiş ve ağır cezalara başvurmuşlardır. Ancak daha sonra bunları vergilendirerek gelir sağlayabileceklerinin farkına varmaları devletlerin konuya bakışını önemli ölçüde değiştirmiştir. Son dönemlerde devletin bu mal ve hizmetlerin tüketimini kısmak için mi yoksa daha fazla gelir elde etmek için mi fazladan vergilendirmeye gittiği tartışılmaya başlanmıştır. Bu çalışmada yüksek günah vergilerinin gerçekten sosyal amaca ulaşmada etkin olup olmadığı konusu ele alınmıştır. Sosyal amaç etkinliği açısından da günah vergilerinin yakından ilişkili olduğu (aile içi) şiddet olayları dikkate alınmıştır. Bunun için de artan vergi oranları karşısında tüketim eğiliminde meydana gelen değişimler ve bu tür malların kullanımına bağlı olarak (aile içi) şiddet olayları ilişkisi irdelenmiştir.

Anahtar Kelimeler: Günah Vergileri, Rasyonel Bağımlılık, Şiddet Olayları

JEL Sinıflandırması: E26, E61, H21

\section{The Sin Taxes Impact on Violence Incidents}

\begin{abstract}
In the old times, governments had gone to ban the consumption of certain goods and services that's considered as sin, and had resorted to heavy penalties. After then, releasing of aware of states to taxing these goods and services had changed view point of states. Recently, discussion has begun if governments levy extra taxes on these goods and services to reduce consumption or to obtain more revenue. In this study, the issue of whether or not high sin taxes is really effective in achieving social purposes has been discussed. Violence incidents (domestic violence) have been taken into account in terms of social purpose effectiveness which is closely related to sin taxes. For this, changes in tendency of consumption, and depending of using of such goods in parallel with increasing tax rates have been studied in accordence of (domestic) violence.
\end{abstract}

Keywords: Sin Taxes, Rational Addiction, Violence Incidents

JEL Classification: E26, E61, H21

Geliş Tarihi / Received: 02.11.2017 Kabul Tarihi / Accepted: 24.12.2017

\footnotetext{
* Arș. Gör., Dokuz Eylül Üniversitesi, İIBF, Maliye Bölümü, abdulkerim.eroglu@deu.edu.tr, https://orcid.org/00000003-2680-8844

**Prof. Dr., Dokuz Eylül Üniversitesi, İİBF, Maliye Bölümü, haluk.egeli@gmail.com, https://orcid.org/0000-00024572-7911
} 


\section{GİRIŞ}

Alkollü içecekler, sigara, uyuşturucular ve daha pek çok maddenin kullanımı kullanan bireylerin sağlığında ciddi problemler meydana getirdiği gibi ekonomik ve sosyal hayatın bütününde de telafisi zor hasarlar meydana getirmektedir. Peki, bu sorunun azaltılmasinda uygulanan cezaların şiddetlendirilmesi ne kadar etkilidir? Ya da daha özel olarak sormak gerekirse hukuki yaptırımlardan daha etkin olarak izlenebilecek bir politika mümkün müdür?

Hiç şüphesiz zararlı mallar içerisinde toplumsal sorunlara yol açanlardan en önemlisi alkollü içeceklerdir. Ölümcül trafik kazalarından aile içi şiddete kadar birçok sorunun birinci dereceden sorumlusu olarak dikkat çekmektedir. Yukarıda değinildiği gibi cezaların artırılması bu sorunun azaltılmasında etkili olacaktır. Ancak ekonomik olarak değerlendirildiğinde bunların denetlenmesi, hukuki sürecin işletilmesi ve cezalandırmaların tamamı ekonomik bir kayıp olarak karşımıza çıkacaktır. Diğer bir deyişle Pigovian vergi, yani dışsallıkların maliyetinin kamu tarafından yüklenilmesi sorunu ortaya çıkacaktır.

Günah vergilerinin konu olduğu mal ve hizmetler için sadece vergilendirmenin değil, aynı zamanda yasaklamaların da bir maliyet unsuru olduğu; zira bu mal ve hizmetlerin yasaklanmasıyla alım-satıma konu olmaya devam ettikleri görülmektedir. Yasaklamaların getirdiği fazladan maliyetler karşıllğında küçük yatırımcıların dışlandığı ve kartellerin oluşmasına zemin hazırlandığı bir alan oluşturmaktadır. Dolayısıyla çalışmada bu yasaklamaların varlığının "ahlaki", "sosyal" ve "iktisadi" amaçlara ulaşmada ne kadar etkin ve gerekli olduğu konusunda da bazı düşüncelere yer verilecektir. Nitekim uyuşturucuların yasaklanması, alkol ve sigara gibi zararlı malların fazladan vergilendirilmesi gibi konular hakkında, ahlaki, sosyal ve iktisadi açıdan tamamen farklı görüşlerin hâkim olduğu görülmektedir. Varılan görüş ve oluşturulan teorilere geçmeden önce günah vergisi kavramı ve özellikleri hakkında bilgi verilmesi önem arz etmektedir. Bu bağlamda, çalışmada öncelikle günah vergisi kavramı açıklanmış, ardından günah vergisi aktörleri hakkında bilgi verilmiştir. Son üç bölümde ise günah vergilerinin tarihsel gelişimi hakkında bilgi verildikten sonra, şiddet olayları ile olan ilişkisi ele alınmıştır.

\section{GÜNAH VERGISIININ KAVRAMI VE ÖZELLIKKLERİ}

\subsection{Günah Vergisi Kavramı}

Günahtan kastedilen unsur herhangi bir dini perspektiften günah olarak kabul edilen fiil değildir. Burada daha çok bağımlılık yapan, eylemi gerçekleştiren kişiye zararlı ve sosyal olarak istenmeyen hareketler kastedilir. Örneğin, spor otomobil kullanmak ekonomik açıdan günah olarak kabul edilmez ancak aynı araç için benzin kullanmak çevreye zarar vereceğinden günahtır. Aynı şekilde alkollü içecek onu kullanan birey ve o bireyin ait olduğu toplum için zararlı olacağı için günahtır (Lorenzi, 2004: 60).

Zararlı mal ve hizmet tüketimlerinin kontrol altına alınması ve sınırlandırılması günah vergilerinin konusuna girmektedir. Amaç olumsuz dışsallığ 1 azaltmak olan, (örneğin çevreye zararlı emisyona sebep olan üretim faaliyetinin marjinal maliyetini artırmak için yapılan düzenlemeler gibi) günah vergileri düzenleyici vergi (corrective tax) olarak da adlandırılmaktadır (Hyman, 2010: 106).

\subsection{Günah Vergisinin Özellikleri}

Günah vergileri yasaklayıcı vergiler değil, daha çok keyif verici, alışkanlık ve bağımlılık yaratan ve inelastik olan talebin cezalandırılması olarak görülmelidir. Diğer bir değişle bireyin cezalandırılması değil davranışın cezalandırılması söz konusudur. Ancak neyin günahkâr olduğu 
konusunda karar vermek hem pratik hem de felsefi açıdan kolay değildir. Hangi malın tüketimi veya hangi davranışın günahkâr olduğu konusunda bir fikir birliği olması yine de sorunun aşılmasında yeterli değildir. Günahkâr olduğu kabul edilen davranışın tamamen yasaklanması veya caydırmak için tedbir alınması konusunda yine bir kararın verilmesi gerekmektedir. Vergi konusunun belirlenmesi zor olsa da günah vergisi için bazı temel kriterler geliştirilmiş̧ir (Lorenzi, 2004: 60):

-Tüketim talebinin inelastik olması gerekmektedir. Verginin artırılması yüksek miktarda vergi gelirine sebep olurken tüketici davranışlarından küçük değişikliklere sebep olmaktadır.

-Talep edilen mal veya hizmetin birey için zararlı olması gerekir. Söz konusu mal veya hizmet uzun vadede bireyin sağlığına zarar veren bir alışkanlıktır.

-Sadece bireyin kendisi için değil; aynı zamanda toplumun diğer üyeleri için de zararlı sonuçlar ortaya çıkmaktadır. Böyle davranışlar toplumsal refah kaybına da sebep olmaktadır.

Tüketim davranışlarının cezalandırılması için yukarıda sayılan kriterlerin tamamının veya birkaçının gerçekleşmesi gerekmektedir. Örneğin, kumar oynamak toplumun geri kalanı için herhangi bir sorun oluşturmadığı gibi bireyin kendisinin sağlığı için de bir tehlike oluşturmamaktadır. Ancak bağımlılık yapan bir davranış olması günah vergisinin konusuna girmesi için yeterlidir.

Günah vergilerinin özelliklerinden biri de regresif vergi özelliği taşımasıdır. Yapılan çalışmalarda özellikle alkollü içecekler ve sigara üzerinden alınan vergilerin artırılması verginin regresif karaktere girmesine sebep olmaktadır (Lyon ve Schwab, 1995: 389). Günah vergilerinin bu tür malların tüketiminden caydırma konusunda önem taşımasının yanında regresif olmaları ve bununla birlikte bu tür malların daha çok yoksullar tarafından tüketilmesi günah vergilerinin vergilemede adalet ve eşitlik ilkelerine ters bir durum meydana getirdiği ileri sürülmektedir (Lockwood ve Taubinsky, 2017: 1,31).

\section{GÜNAH VERGILERIININ AKTÖRLERİ}

Günah vergileri söz konusu olduğunda gerek vergi tabanının gerekse vergi oranlarının belirlenmesinde çeşitli aktörler rol oynamaktadır. Her bir aktör grubu kendi çıkarları doğrultusunda hareket etmekte ve bu durum çıkar çatışması haline gelebilmektedir.

Günah vergilerinde rol alan başlıca aktörler şunlardır (Johnson ve Meier, 1990: 578-582):

Dini Gruplar: Günah vergilerinin konusuna giren pek çok mal ve hizmet dini grupları yakından ilgilendirmektedir. Bu tür eylemlerin sadece ekonomik yönüyle değil sosyal yönüyle de ilgilenen dini gruplar içki, kumar ve zina gibi birçok eyleme sert tavır almaktadırlar. Onlara göre arınmanın ve iyi insan olmanın koşulları arasında bu türden alışkanlıklardan uzak durmak da yer almaktadır. Bu yüzden dini gruplar politika yapıcılar üzerinde baskı oluşturarak günah vergilerinin aktif olarak kullanılmasını savunmaktadırlar. Cezalandırma aracı olarak gördükleri vergiler sayesinde bireyler zararlı (günah) olan davranıştan vazgeçecektir.

Endüstri: Sigara, alkollü içecekler gibi ürünlerin üreticileri piyasadaki diğer üreticiler gibi karını maksimize etmek istemektedirler. Ürünlerin üzerine konulacak fazla vergi malın satış fiyatına yansıtılacağından talep edilen miktarı azalacak ve üreticinin karında düşüş meydana gelecektir. Turizm endüstrisinin gelişmiş olduğu yerlerde de, alkollü içeceklerin tüketim yoğunluğuna bağlı olarak, alkollü içeceklere getirilecek fazladan vergiler hoş karşılanmayacaktır.

Bireyler: Bireyler için önemli olan yüksek vergi ödememek olduğu için sınırlı bir kesimi ilgilendiren günah vergileri her bir birey için kitlesel anlamda çok önem arz etmemektedir. 
Nitekim günah olan mal ve hizmet fiyatının içinde gizlendiği için bireyler mali anestezi dolayısıyla ödedikleri verginin farkında olmazlar.

Politikacılar: Politikacıların öncelikli kaygıları tekrar seçilmek olduğu için oy verenlerin taleplerini yerine getirmeye çalışırlar. Bu taleplerle birlikte politikacıların yapmaları gerekenler arasında zararlı alışkanlıkları konusunda düzenleyici önlemlerin alınması da yer almaktadır (Gruber ve Koszegi, 2002: 1). Vergi politikaları belirlenirken en az oy kayb1 yaratacak politikalar tercih edilir. Günah vergilerinin vergi gelirleri içinde çok daha büyük paya sahip olan vergiler içinde daha az görünür oldukları için artırılmaları bir sorun olarak görülmez.

\section{GÜNAH VERGILLERINIIN TARIHHSEL GELISŞIMI}

Günah vergileri konusunda tarihte ilk dikkat çeken gelişme Amerika'da viski üzerinden alınan vergidir. Amerika'nın bağımsızlık savaşı (1775-1783) sonrası altına girdiği borç 75 milyon dolara kadar çıkmıştı ve bu borcun ödenmesi için ülkede çok karlı bir iş olan viski üretimi hedef alındı. Daha sonra Viski İsyanı (1794) olayıyla anılacak bu vergi Amerika'nın aynı zamanda ilk federal vergisi unvanını almıştır. Başkan Thomas Jefferson tarafından kaldırılan viski vergisi İç Savaş dönemine kadar gündeme getirilmedi. İç Savaştan (1861-1865) sonra ortaya çıkan büyük finansman sorunları alkollü içeceklerle birlikte birçok mal türüne ve kişisel servetlere ağır vergiler getirilmesine neden oldu. Sonraki yıllarda farklı vergileme arayışlarına gidilmiş ve nihayet gelir vergisi alınmaya başlayınca zamanla alkollü içecekler üzerinden alınan vergilerin önemi azalmaya başlamıştır (Thornton, 2004:365).

Amerika'da meydana gelen Viski İsyanından önce, yine viski damıtıcıları tarafından çıkartılan başka bir isyan da İskoçya'da meydana gelmiştir. İskoçya'nın Birleşik Krallığa dâhil olmasından sonra (1707), Birleşik Krallık İskoç viski damıtıcılarına ağır vergiler getirdi. Vergi memurlarının sert müdahalelerde bulunmaları ve üreticilerin vergi ödemek istememeleri sonucu 1715 yılında şiddetli bir ayaklanma oldu. Ayaklanma Birleşik Krallı̆̆ın İskoçya'yı işgal etmesiyle sonuçlandi.

Papa 10. Leo (1475-1484) papalık yaptığı dönemde binlerce kayıtlı hayat kadınları için günah vergisi getirmiştir. Kadınların ruhlarının arafta kalmaması için belli bir ücret almış ayrıca günah çıkarma ücretlerini de artırmıştır. Papa 2. Clement (1046-1047) de papalık yaptığı dönemlerde genelevlerinin gelirlerinin Kilise'ye aktarılmasına karar vermiş, ayrıca fahişelikle suçlanan kadının hayatta olup olmamasına bakılmaksızın sahip olduğu servetin yarısının bir manastıra bahşedilmesine karar vermiştir (Lorenzi, 2004: 59).

Modern dünyada günah vergileri içerisinde yer almasa da 18. ve 19. yüzyıllarda köleler üzerinden alınan vergilerin de, tarihsel dönemler itibariyle günah vergisi olarak değerlendirilmesi mümkündür. Ahlaki olmayan bir davranış yasaklanamıyorsa, yapılacak en önemli caydırıcılık vergilendirilmesidir. Örneğin, Amerika'da 1808 yılına kadar ithal edilen her köle başına 10 Dolar vergi alınmaktaydı 1798 yılında çıkarılan bir kanunla herkes sahip olduğu konutlar, topraklar ve köleler üzerinden vergi ödemekle mükellef oldu. 1802 y1lında finansman ihtiyacının azalmasıyla köle vergisi kaldırıldı 1812 Savaşında (War of 1812) finansman ihtiyacının artmasıyla vergiler tekrar yürürlüğe girdi ve 1815-1816 yıllarında artırılarak uyguland1. 1817 yılında da tamamen kaldırıldı (Newman, 2004: 1-8).

Osmanlı döneminde de alkollü içecekler üzerinden alınan vergiye "şıra resmi" ve daha sonra "zecriye", "reftiye", "idhaliye" gibi isimler verilmiştir. Bu vergiye ek olarak alkollü içecek satanlar için bir çeşit ruhsat harcı olan "resm-i beyiye" de sayılabilir. 1863 yılında da tütün ürünleri satışından "tönbeki beyiyesi” ismiyle vergi alınmıştır (Batırel, 2002: 4-8).

Tarih boyunca birçok devlet alkollü içecekleri, fahişeliği, tütün ürünlerini yasaklamak istemiş ve bunun için ölüme kadar giden cezalar getirmişlerdir. Ancak daha sonra bunların 
vergilendirilmesiyle devlet gelirlerinin artırılacağı görülmüş ve bunların yasaklanmasından vergilendirilmelerine doğru bir geçiş süreci yaşanmıştır.

\section{GÜNAH VERGILERINIIN ETKİNLİĞİ: RASYONEL BAĞIMLILIK TEORİSI}

Günah vergilerinin zararlı malların kullanımını kısıtlaması birçok araştırmacı tarafından test edilmiş, bağlantı arasındaki ilişki kurulmaya çalışılırken çoğunlukla "rasyonel bağımlılık teorisi-RBT" (theory of rational addiction) dikkate alınmıştır. Rasyonel bağımlılık teorisi o kadar geniş bir uygulama alanı bulmuştur ki, sadece alkol, sigara veya uyuşturucu değil; bağımlılık yaptığı kabul edilen birçok mal rasyonel bağımlılık teorisi perspektifinden test edilmiştir.

RBT'de bağımlılıkla ifade edilen; bir malın mevcut tüketiminin artması aynı malın gelecekteki tüketimini de artırması durumudur (Becker, 1996: 57). Teoride önemli olan bağımlılık ile bitişik tamamlayıcılık ${ }^{1}$ (adjacent complementarity) arasındaki ilişkinin varlı̆̆ıdır. Bitişik tamamlayıcılık şimdiki zaman tüketiminin marjinal faydasının geçmiş zaman tüketim stokuna bağlı olarak artmasını ifade eder (Becker ve Murphy, 1988:681; Cawley ve Ruhm, 2012: 212).

RBT’nin bağımlı olarak ele aldığı bireyler "miyobik bireyler" değil, "rasyonel bireylerdir". Diğer bir deyişle RBT şimdiki-zaman odaklı bağımlıların değil, gelecek-zaman odaklı bağımlıların davranışlarını açıklamaya çalışır. Miyobik-rasyonel bireyler açıklanmaya çalışılırken dikkate alınan hem bireyler hem de bağımlılık yapan zararlı malların bireyler üzerindeki etkileridir. Örneğin, bir birey bazı mallara bağımlı olabilirken başka bir birey için aynı mallara bağımlılık söz konusu olmayabilir. Benzer şekilde bir mal bazı bireyler için bağımlılık yaparken diğer bireyler için bağımlılık yapmayabilir. Farklı durumlara rağmen RBT'nin kabul ettiği durum şudur: Şimdiki-zamana odaklı bireylerin, gelecek-zamana odaklı bireylere göre zararlı mallara bağımlı olması daha yüksek bir ihtimaldir (Becker ve Murphy, 1988: 682). Bağımlılık yapan malın gelecek-zaman fiyatlarının artacağı beklentisi şimdikizaman tüketimini azaltır. Bu negatif ilişki rasyonel bağımlılığı miyop davranışlardan ayırt eden en önemli unsurlardan biridir (Becker ve Murphy, 1988: 689).

Yakın geçmişte fiyatlarda meydana gelen değişme şimdiki zaman tüketimi üzerinde daha uzak geçmişteki fiyat değişiminden daha büyük etki gösterir. Fiyat artışlarının kalıcı olması da geçici fiyat değişmelerine göre daha fazla etkili olur. Benzer şekilde gelecek-zaman fiyatlarının düşeceği veya gelecek-zamanda stres yapan boşanma, iş kaybı veya sevilen birinin ölümü gibi olayların olacağı (veya artacağı) beklentisi de zararlı bağımlılık yapan malların kullanımını artıracaktır. Bu bakımdan bağımlılık yapan zararlı malların kullanımı ilk dönemlerde her zaman haz almakla ilgisi olmayabilir ancak daha sonraki dönemlerde bu malların kullanımını engellemeye çalışmak mutsuzluğu (veya yoksunluk duygusunu) daha çok artıracaktır. RBT'ye göre bağımlılık yapan zararlı malların bırakılabilmesi için en etkin yöntem "soğuk hindi" (cold turkey) yöntemidir. Bu yöntem ile kısa vadeli "acı"ya rağmen birey zararlı malın kullanımını aniden terk etmektedir. Rasyonel bireyden de bu yöntemle zararlı alışkanlığını sona erdirmesi beklenmektedir (Becker ve Murphy, 1988: 692-693).

RBT'ye göre fiyatlarda meydana gelen artış zararlı malların tüketimini azaltacaktır. Diğer bir ifadeyle bağımlılık yapan malların kullanımı fiyattan tamamen bağımsız değildir. Fiyat

\footnotetext{
1 Ryder ve Heal (1973: 5) bitişik tamamlayıcıllk ile birlikte mesafeli tamamlayıcıllk (distant complementarity) kavramlarını beraber ele almıştır. Bir kişinin ağır bir akşam yemeği yemeyi umduğu bir günde sağlam bir kahvaltı ve hafif bir öğle yemeğiyle günü geçirmesi mesafeli tamamlayıcılık; aynı koşullarda hafif bir kahvaltı ve sağlam bir öğle yemeğiyle akşam yemeğini beklemesi ise bitişik tamamlayıcılığa örnek olarak gösterilebilir.
} 
değişiklikleri kısa vadede talep üzerinde sınırlı bir etkiye sahip olmakla birlikte, uzun vadede bu etki daha güçlü olmaktadır.

Mullahy yaptı̆̆ elastikiyetini 0.47 olarak hesaplamıştır. Hesaplamalarda erkeklerin fiyat değişmelerine, kadınlara kıyasla, daha yüksek tepki verdikleri sonucuna ulaşmıştır (Chaloupka vd., 2000: 114). Becker ve arkadaşları ise sigaranın fiyatında meydana gelen değişmelerin tüketim miktarı üzerindeki etkisini uzun dönemli olarak ele almış ve talebin fiyat elastikiyetinin daha yüksek olduğunu hesaplamışlardır. Yaptıkları hesaplamalarda sigara fiyatlarında meydana gelen \%10'luk kalıcı bir artış, uzun vadede \% 7.5'luk talep azalmasına yol açtığı sonucuna ulaşmışlardır (Becker vd., 1988: 396). Cook ve Tauchen (1982: 380), alkollü içecek fiyatlarında meydana gelen değişmelerin talep üzerindeki etkisini çok farklı bir yöntemle test etmişlerdir. Buna göre alkollü içecek fiyatlarında yapılan 1 birimlik özel tüketim vergisi artışının siroz hastalığına bağlı ölüm oranlarını kısa vadede \%5.4 kadar azalttığı, uzun vadede ise azalmanın iki katına kadar çıkabileceğini tahmin etmişlerdir.

Bağımlılık yapan zararlı malların fiyatlarında meydana gelen değişmenin yanında talebi etkileyen başka unsurlar da söz konusudur. RBT'ye göre rasyonel bir birey gelecekteki faydalanmaların parasal değerinde meydana gelen değişimleri ve şimdiki-zaman tüketiminde meydana gelen değişime uyarlanmış gelirini dikkate alır ve satın alma pozisyonunu yeniden belirler. Yani birey bağımlı olduğu malın fiyatında meydana gelen değişimleri ve şimdikizamanda tükettiği malın fiyatının geliri üzerinde meydana getirdiği etkiyi dikkate alarak “tüketim sermayesi”ni (consumption capital) rasyonel olarak kullanmaya gayret eder (Becker, 1996: 63).

Bağımlılık yapan zararlı malların kullanımı ile eğitim arasındaki ilişki konusunda farklı görüşler söz konusudur. Bir kısım araştırmacılara göre herhangi bir ilişki söz konusu değilken (Kenkel, 1991:303) diğer araştırmacılara göre iki değişken arasında negatif bir ilişki vardır. Bu konudaki ilk çalışmalardan biri Farrel ve Fuchs tarafından yapılmış ve çalışmada bireylerin cinsiyetine ve yaşına bağlı olarak sigara kullanma ile okula gitme süresi arasında negatif bir ilişki olduğu sonucuna ulaşılmıştır (Farrel ve Fuchs, 1981: 14). Gilman ve arkadaşları ise negatif ancak sınırlı bir sonuca ulaşmışlardır (Gilman vd., 2008: 622).

RBT'nin ekonomik ve sosyal hayatta geçerli olmadığını, bağımlılık yapan zararlı malların kullanımıyla fiyat değişmeleri arasında bir ilişki olamayacağını savunanlar da vardır. Özellikle fiyatların artması durumunda zararlı malları oluşturan sektörlerin yeraltına ineceği, bu yüzden bu tür malların fiyatlarında özel olarak yapılacak artırımların etkin olamayacağını vurgulamaktadırlar. RBT'ye getirilen eleştirileri şu şekilde sıralanabilir (Thornton, 2004: 364365):

-Özel tüketim vergileri hedeflenen malın tüketimini ortadan kaldırmaz.

-Yasaklamalar gibi özel tüketim vergileri de daha güçlü ve potansiyel olarak daha zararlı malların üretimini teşvik eder.

-Bir malın günah olarak değerlendirilebilmesi genç bireyler ve erkek çocuklar gibi potansiyel olarak riske meyilli gruplar için o malın kullanımı cezp edici bir hal alır.

-Özel tüketim vergileri, tüketicileri vergisiz ancak daha düşük kaliteli ve daha zararlı malların kullanımına yönlendirecektir.

-Günah vergileri kayıtdışı ekonominin gelişmesini teşvik edecektir.

-Tam olarak hangi malın vergilendirilmesi gerektiğinin belirlenmesi olanaksızdır.

-Optimum bir vergi oranının belirlenmesinin herhangi bir yolu yoktur.

-Yapıları itibariyle vergi politikaları ve oranları siyasi olarak değişkendir. 
Thornton'a göre günah vergileri alkollü içeceklerin ortalama tüketimini azaltmaktadır; ancak günahın kendisini hedef almadığ 1 için günahı azalttığı konusu çok net değildir. O'na göre alkollü içeceklerin beşeri sermayeyi tahrip ettiği, şiddeti, intiharları, trafik kazalarını ve suç oranlarını arttırdığı, sağlığa zarar verdiği konusunda çok net bir sebep-sonuç ilişkisi yoktur (Thornton: 2004: 366). Yapılan çalışmalarda 1lımlı içicilerin mortalitesinin içmeyenlere veya ağır içicilere göre daha düşük olduğu görülmüştür (Camargo vd., 1997: 82; Yuan vd., 1997: 20). Ancak sigara için durum değişir. Çünkü sigaradan kaynaklanan hastalıkların ortaya çıkma ihtimali içki kullanımıyla birlikte artmaktadır (Doll vd., 1994: 913).

Chaloupka ve arkadaşlarının yaptıkları çalışma sonucunda ise alkollü içeceklere yapılan vergi artışlarının ölümcül trafik kazalarında ciddi azalışlar meydana getirdiği sonucuna ulaşılmıştır (Chaolupka vd., 1991: 20)2. Thornton günahın kendisini hedefleyen idari yaptırımların daha etkin bir caydırıcılık özelliği göstereceğini savunmuştur. O’na göre günah vergileri günahın kendisini doğrudan hedeflememektedir (Thornton, 2004: 367).

Toplumsal dişsal maliyetlerin vergiler yoluyla içicilere yükletilmesi gerektiği iki sebebe dayanmaktadır. Birincisi içicilerin tercihleri dolayısıyla sebep oldukları dışsal maliyetleri karşılamaları daha adildir, ikincisi alkol fiyatları sosyal maliyetlerin tamamını yansıtmadığı takdirde içiciler daha çok içecek ve teknik anlamda içme marjlarının sebep oldukları maliyetlerden daha az değerli olacaktır (Cook ve Moore, 2002: 129).

\section{GÜNAH VERGILERININ ŞIDDET OLAYLARINI AZALTMADAKİ ETKİNLİĞİ}

Alkol tüketimi ile şiddet olayları arasındaki ilişki birçok boyutta ele alınmıştır. Alkol tüketiminin fiziksel ve davranışsal sonuçlarına bakıldığında (Carpenter ve Dobkin, 2009: 164) özellikle aile içi şiddet başta olmak üzere, cinsel saldırılar, soygun vakaları, intihar, cinayet ve ölümcül trafik kazaları ile alkol tüketimi arasındaki ilişki üzerinde dikkatle durulmaktadır.

Aile içi şiddete yönelik çalışmalar daha çok kadının ve küçük çocukların maruz kaldığ 1 şiddet ile şiddeti uygulayan bireyin alkollü içecek tüketmesi veya diğer herhangi bir uyuşturucunun etkisi altında olup olmaması dikkate alınmaktadır. Genellikle bu tür ilişkiler aranırken değişkenlere hanehalkı sayısı, medeni durum, yaş, eğitim durumu ve/veya etnik yapı gibi unsurlar dâhil edilir.

Şiddet olaylarına bakıldığında alkolün önemli bir etkisi olduğu görülmektedir. Genellikle böyle durumlarda sert tartışmaların seyri alkolle birlikte şiddete dönüşmekte veya şiddet gören kişinin alkol almasıyla karşısındakini şiddet için tahrik edecek davranışlar sergilemeye başlamaktadır. Aile içi şiddet olaylarında ise daha çok erkeğin alkollü olmasından kaynaklanan şiddet olayları yaşanmaktadır. Böyle durumlarda meydana gelen şiddet olayları dolayısıyla (diğer durumlarda meydana gelen şiddet olaylarına kıyasla) daha ağır yaralanmalar meydana gelmektedir. $\mathrm{Bu}$ durum eşlerin birbirine uyguladıkları şiddet olaylarında alkolün sınırlandırmaları-yasakları kaldırma gücünün etkisi olarak bilinen "şiddetli etkiler hipotezi" (acute effects hypothesis) ile açıklanmaktadır (Caetano vd., 2001: 59).

T.C. Başbakanlık Aile Araştırma Kurumu Başkanlığı'nın (1995: 131) yaptığı anket sonuçlarına göre erkeğin kumar alışkanlığı ve evle ilgilenmemesinin yanında aşırı alkol kullanmasının eşler arasındaki ilişkinin kavgaya dönüşmesindeki en etkili nedenler arasında olduğu sonucuna varılmıştır. Charles ve Perreira'a (2007: 617) göre, erkeklerin uyuşturucu

\footnotetext{
${ }^{2}$ Ayrıca vergi artışlarıyla birlikte sert cezaların ve alkollü içecek tüketim yaşının yükseltilmesi gibi idari önlemlerin artırılmasıyla daha etkin sonuçlar elde edebileceği sonucuna varılmıştır.
} 
kullanmaları veya sık sık alkollü içecek tüketmeleri hamilelik ve sonrası dönemlerde eşlerine şiddet uygulama riskini artırırken, kadınların alkol kullanmaları halinde ise sadece hamilelik dönemlerinde şiddet görme riskini artırmaktadır. Burada hamilelik döneminde şiddet eğilimini en yükseğe çıkarabilecek unsurlar şunlardır: (1) kadınların resmi nikâhlı olmayan eşleri, (2) yüksekokuldan daha düşük bir eğitim seviyesinde olmaları ve (3) eşlerinin geçmiş-zamanda uyuşturucu ve/veya alkol kullanmış olması. Özellikle hamilelik döneminde kadının çalışmıyor olması hamilelikten sonraki bir yıllık süre boyunca şiddet görme ihtimalini daha fazla artırmaktadır.

Aile içi şiddetin bir diğer önemli muhatapları küçük çocuklardır. Küçük çocukların şiddete maruz kalmalarıyla alkollü içecek fiyatları arasındaki ilişki anlamlı görünmektedir. Alkollü içecekler üzerindeki özel tüketim vergilerinin \%10 oranında artırılması küçük çocuklara yönelik ağır şiddet olayları üzerinde $\% 2.3$, diğer şiddet olaylarının üzerinde ise $\% 1.2$ oranında azalma meydana getirmektedir (Markowitz ve Grossman, 1998: 319-320). Bir başka araştırmada alkol fiyatlarının özel tüketim vergileri yoluyla artırılmasının cinsel suçlar ve soygun gibi olaylar üzerinde etkili olmadığı, ancak diğer saldırı türleri üzerinde etkili olduğu sonucuna varılmıştır (Markowitz, 2005: 38).

Coker ve arkadaşları (2000: 558-559) ise erkeğin işsiz olmasının yanında alkol veya uyuşturucu bağımlılı̆̆ söz konusu olduğu durumların birçok şiddet olaylarıyla çok güçlü bir bağl1lık içinde olduğu sonucuna varmışlardır. Buna göre alkol ve uyuşturucu kullanan işsiz birinin şiddete yönelme ihtimali alkol veya uyuşturucu kullanan ancak çalışan birine göre iki kat daha yüksektir.

Durance ve arkadaşlarının yaptıkları çalışmada alkollü içeceklere getirilen vergilerin tüketimi azalttığı, ancak tüketimde meydana gelen bu azalmanın kadınlara yönelik şiddet olayları üzerinde istatistiksel olarak çok ciddi bir etkisi olmadığı sonucuna varmışlardır (Durance vd., 2011: 174). Alkollü içecek fiyatlarında meydana gelen artışın tüketim miktarını azalttığı konusunda aynı sonuçlara varan Chaloupka ve arkadaşları ise alkollü içecek fiyatlarında meydana gelen artış ile şiddet olayları konusunda farklı sonuçlara varmışlardır. Fiyat artışlarıyla birlikte alkol tüketiminin azalması hastalıkların, kazaların, alkole bağlı ölümlerin ve bunlarla birlikte alkolle bağlantılı şiddet olaylarının oranında bir azalma olduğu sonucuna varmışlardır (Chaloupka vd., 2002: 22). Page ve arkadaşlarının yaptıkları çalışmada da enflasyon oranı üzerinde yapılan bir fiyat artışının şiddet olaylarının azaltılmasında etkili olduğu sonucuna varılmıştır. Yaptıkları çalışmada ayrıca market gibi doğrudan hanehalkına satış yapılan yerlerde (on-trade) alkol fiyatlarının artırılmasının şiddet vakalarının azalması konusunda, bar, restoran, otel gibi yerlerde satılan (off-trade) alkol fiyatlarının artırılmasından daha etkin olduğu sonucuna ulaşmışlardır (Page vd., 2017: 33,38).

Becker günah mallarının tüketimi dışında şiddet olaylarının hukuki yaptırımlarını da ele almıştır. Ekonomik bir analizle yasadışı faaliyetlerle mücadelede optimal kamu ve özel politikalarının neler olabileceği üzerine yaptığı çalışmada çok ilginç bir şekilde şiddet olaylarının artışının dolaylı göstergelerinden biri olarak piyasadaki nakit miktarının artması olduğunu iddia etmektedir (Becker, 1974: 4). O'na göre eğer iktisatçılar yasal işlere girenleri tanımladıkları gibi yasadışı işlere girenleri tanımlayacak olurlarsa, bunlar risk tercih edenler (risk preferrers) olarak tanımlanacaklardır (Becker, 1996: 44). Burada tıpkı herhangi bir girişimcinin risk faktörünü göze alarak bir girişimde bulunması gibi yasadışı bir faaliyete girişen biri de risk faktörünü göze alarak karlılığını artırmak istemektedir. Sıradan bir girişimciden farklı olarak yakalanma ve cezalandırma maliyetlerine de katlanmak zorunda bırakılmaktadırlar.

Günah vergilerinin toplam fiyatını ne kadar arttırdı ̆̆ı da önem taşımaktadır. Alkollü içeceklerin fiyat artışları özel tüketim vergilerinde meydana gelen artışlardan daha yüksek gerçekleşmektedir. Genel satı̧s vergilerinin alkollü içecek talebinin ikame etkisinde meydana getireceği sınırlandırıı etki özel tüketim vergilerinin etkisinden daha fazladır. Başka bir deyişle 
alkollü içeceklerin az sayıda insanın harcama kalemleri içinde yer alacağından genel satış vergileri talep üzerinde daha yüksek bir gelir etkisi göstermektedir. Alkollü içecekler üzerindeki tüketim vergileriyle birlikte artan fiyatlar kişi başına düşen tüketim miktarında azalmayla sonuçlanmaktadır. Tüketim miktarını azaltan bir vergi artışı kısa dönemde birçok nedene bağlı ölüm oranlarını düşürmektedir (Young ve Bielinska-Kwapsiz, 2002: 71; Cook vd., 2005: 11). Bununla birlikte Thornton günah vergilerinin etkin olmadığını farklı gerekçelere bağlayarak iddia etmektedir. Ancak yaptığı çalışmalarda etkinsizlik boyutunu 1929 Buhranı dönemlerine denk gelen yasaklamaların ters yönde etki gösterdiği ve bunun o dönemin verilerinde açıkça görüldüğünü söylemektedir. Nitekim o dönemlerde yapılan yasaklamalar bazı malların kullanımını azaltmamış aksine artırmıştır. Ancak 1929 Buhranının görülen en sert ekonomik kriz olması, dolayısıyla sosyal ve ekonomik yaşamın olağan akışının çok dışında bir durum olması yapılan eleştirinin genel-geçerliğini sorgulatmaktadır.

Thornton ve Becker'ın vardıkları sonuçları iki boyutlu ele alan Milton Friedman'a göre, doğrudan bireylerin tercihleri üzerinde herhangi bir sinırlama etkin olmayacaktır. Thornton'un öne sürdüğ̈ gibi; alkol yasakları alkolün daha fazla tüketilmesine yol açtığını belirten Friedman'a göre, alkole bağlı ölümlerde en sert yükseliş yasaklama dönemine denk gelmektedir. Friedman, Becker'ın tanımladığı risk tercih edenler grubunu ise "devlet tarafindan korunan karteller" olarak tanımlamıştır. Friedman'a göre, uyuşturucu ticareti gibi faaliyetlerin yasadış1 olmasından dolayı sınırlı sayıda kişi bu sektöre girebilmekte ve dolayısıyla karteller meydana gelmektedir. Bunun da doğal sonucu olarak fiyatların çok yükselmesi olmaktadır.

Şiddet olaylarıyla uyuşturucu gibi malların yasadışı kabul edilmesine birçok iktisatçıdan farklı bir şekilde bakan Friedman, uyuşturucunun devlet eliyle yasaklanmasının her yıl ortalama on bin insanın ölümüne neden olduğunu söylemektedir. Böyle yasaklamaların bireysel özgürlüklere müdahale olduğunu ve "devletin, bireyleri kendi iyilikleri için olsa dahi, müdahale hakkının olmadığını” savunmuştur. O’na göre nasıl ki devlet aşırı yemek yemenin ölümle sonuçlanmasına veya paraşütle atlanmasının yüksek hayati risk içermesine rağmen devlet tarafından yasaklanmıyorsa, bireylerin uyuşturucu kullanma hakkına da müdahale etmemelidir (Friedman, 1991). John Stuart Mill de benzer olarak kişilerin zehirli bir mal kullanması halinde ancak kişinin çocuk, deli veya akli melaikelerini tam olarak kullanamayan biri olması halinde devlet müdahalesinin gerektiğini ileri sürmüştür (Mill, 1859: 88).

Günah vergilerinin artırılması gibi, ceza ve yaptırımların artırılması da günah mallarının kullanımını sınırlandırmakta ve bu tür malların kullanımına bağlı olarak ortaya çıkan sosyal kayıplar da en aza inmektedir. Devletin suçlarla mücadelede kullandığı toplam kaynakların (kolluk kuvvetleri, adli süreçler, cezaevlerinin harcamaları, saldırılara bağlı sağlık harcamaları gibi) büyüklüğüne ve bunların içindeki günah mallarının kullanımına bağlı olarak gerçekleşen olayların oranına bakıldığında sosyal kayıpların ne kadar yüksek olduğu görülmektedir. Avustralya'da bu konuda çalışan Alkol Araştırma ve Eğitim Vakfı (Foundation for Alcohol and Research and Education-FARE) dikkat çekici veriler sunmaktadır. Buna göre alkolle bağlantılı şiddet olaylarında her yıl ortalama 400 kişi yaşamını yitirmekte, 24 bini aile içi şiddetten kaynaklanan 70 bin kişi de yaralanmaktadır. Bütün bunların toplam ekonomik maliyeti ise yıllık ortalama 36 milyar dolar olarak gerçekleşmektedir (FARE, fare.org.au/about Erişim Tarihi: 11.12.2017).

Vergi oranları, cezalar, idari tedbirlerin yanında sübvansiyonlar da günah mallarının kullanımı üzerinde etkiler göstermektedir. Bahsedilen tedbirlerden herhangi biri uygulanabileceği gibi belli kombinasyonlar şeklinde de uygulamalar söz konusu olabilir. Cheng ve Chu (2017: 15-16) yaptıkları çalışmada bireylerin miyop olma derecesinin dikkate alınması gerektiği ve buna göre en uygun tedbirin alınması gerektiğini ortaya koymuşlarıdır. Onlara göre günah mallarını tüketen bireylerden gelecekteki sağlı maliyetlerini tam olarak değerlendiremeyenler miyop olarak kabul edilmelidir. Buna göre kullandıkları günah malları 
konusunda 1srarla miyop davranışlarına devam edenler (persistent-error myopes) için tasarrufları sübvanse edecek tedbirlerin yanında vergilendirmenin kullanılması etkin bir çözüm olarak görülmektedir. Miyop davranışlarını değiştirme konusunda daha esnek olan bireyler (dual-self myopes) için ise sübvansiyon veya vergilendirme tedbirlerinden birinin yeterli olabileceğini ileri sürmüşlerdir ${ }^{3}$.

\section{SONUÇ}

Tarihin pek çok evresinde devletler günah olarak kabul ettikleri bir takım malların tüketimini yasaklamaya çalışmış ve ölüm cezalarına kadar giden sert cezalandırmalarla bunları engellemeye çalışmıştır. Ancak devlet yöneticileri bu tür mal ve hizmetleri yasaklamaktansa vergilendirme yoluna giderek vergi gelirlerini artırabileceklerinin farkına varmalarıla yasaklardan vazgeçmişlerdir. Her ne kadar zararlı mal ve hizmetlerin tüketimini sosyal amaçla vergilendirdiklerini beyan etseler de toplam gelir içindeki bu tür mal ve hizmetler üzerinden alınan vergi oranlarına bakıldığında bunun sosyal amaçtan çok mali amaçla yapıldığı izlenimi verilmektedir. Eğer gerçekten devlet vergilendirmeyi sosyal amaçlar uğruna yapıyorsa bu doğrultuda ne kadar başarılı olduğunun da sorgulanması gerekecektir.

Günah vergilerinin muhataplarına bakıldığında normal olarak kimlerin bu tür vergilere karşı geleceğini, kimlerin bu vergilerin daha fazla artırılmasını isteyeceğini tahmin etmek zor değildir. Özellikle dini perspektiften bakanların ve bu mal ve hizmetlerin ticaretiyle uğraşanların iki faklı grup oluşturduğu görülmektedir. İşin politik karar alma noktasında ise siyasetçiler bulunmaktadır. Genel olarak da siyasetçiler kendilerine en fazla oy getirecek kesimin isteklerini dikkate alacaklardır.

Günah vergilerinin sosyal açıdan etkinliğini analiz eden birçok araştırmacı birbirinden oldukça farklı gerekçelerle çok farklı sonuçlara ulaşmışlardır. Öncelikle günah vergilerinin günahın kendisini hedeflemediği için günah vergilerinin etkinsiz olduğunu ve dolayısıyla istenilen sonucu vermeyeceğini savunanlar vardır. Bu gruptaki araştırmacılar alkol ve sigara gibi malların özel olarak fazladan vergilendirilmemesi gerektiğini savunmaktadırlar. Özellikle alkollü içeceklerde 11 mmlı içiciliğin mortalitenin hiç içmeyene veya ağır içicilere göre daha düşük olduğunu, diğer durumlarda oluşabilecek olumsuz olayların varlığı halinde ise zarar veren ve zarar gören bireylerin bunu kendi aralarında çözebileceğini savunurlar. Örneğin Friedman gibi liberal iktisatçılar ortaya çıkabilecek olumsuzlukların devlet mekanizması olmaksızın, piyasanın kendi araçlarıyla çözülebileceğini öne sürmüşlerdir. Dolayısıyla günah vergileriyle bu tür malların tüketimini azaltmaya çalışmanın anlamsız olduğu görüşündedirler. Ancak burada zarar gören ve zarar veren tarafların aynı şartlarda olmama durumu söz konusu olabilmektedir. Özellikle kadın ve çocukların şiddete maruz kalmaları halinde piyasa ekonomisinde olduğu gibi bireylerin bu sorunu kendi aralarında çözebilmeleri için karşıllklı eşitliğin yokluğu bu görüşü çıkmaza sokmaktadır. Böyle durumlarda güçsüz-mağdur olan tarafın korunması üçüncü bir kişi tarafından yapılması kaçınılmaz olmaktadır. Buradaki üçüncü kişi de devlet olmak durumundadır. Diğer tarafta bulunan araştırmacılar da bu tür olaylara işaret etmekte; kadınlara ve çocuklara yönelik gerçekleşen aile içi şiddet, cinsel saldırı, soygun, cinayet, intihar, ölümcül trafik kazaları gibi pek çok olayın alkollü içecek tüketimiyle çok yakından ilişkili olduğunu ve dolayısıyla alkollü içeceklerin tüketimini azaltmak gerektiğini savunmaktadır. Bu gruptakilere göre alkollü içecek satış yaşının artırılması, satış saatlerinin sınırlandırılması gibi hukuksal

\footnotetext{
${ }^{3} \mathrm{Bu}$ politikalar belirlenirken bütün bireylerin farklı miyop durumları hakkında bilgi sahibi olunamayacağı için asimetrik enformasyon sorunu ortaya çıacaktır. Politika yapıcılar tam enformasyona sahip olsalar dahi her gruptaki bireyler için spesifik politikaların belirlenmesi çok maliyetli olacaktır.
} 
düzenlemelerin yanında günah vergileriyle alkollü içecek fiyatlarının artırılması tüketimi ve sonuçta alkolle ilişkili şiddet olaylarını azaltacaktır.

\section{KAYNAKÇA}

Batırel, Ö.F. (2002), Özel Tüketim Vergisi ve 4760 Sayılı Özel Tüketim Vergisi Yasası üzerine bazı düşünceler, Vergi Dünyası, 253, 4-8.

Becker, G.S. (1974), Crime and punishment: an economic approach, In Gary S. Becker ve William M. Landes (Eds.) Essays in the economics of crime and punishment (pp. 1-54), NBER.

Becker, G.S. (1996), Accounting for tastes, Harward University Press, London.

Becker, G.S., Grossman, M. ve Murphy, K.M. (1988), An emprical analysis of cigarette addiction, The American Economic Review, 84(3), 396-418.

Becker, G.S. ve Murphy, K.M. (1988), A theory of rational addiction, Journal of Political Economy, 96(4), 675-700.

Caetano, R., Schafer, J. ve Cundradi, C.B. (2001), Alcohol-related intimate partner violence among white, black, and hispanic couples in The United States, Alcohol Research \& Health, 25(1), 58-65.

Camargo, C.O., Hennekens, C.H., Gaziano, J.M., Glynn, R.J., Manson, J.E. ve Stampfer, M.J. (1997), Prospective study of moderate alcohol consumption and mortality in US male phsicians, Archives of Internal Medicine, 157(1), 75-85.

Carpenter, C. ve Dobkin, C. (2009), The Effect of Alcohol Consumption on Mortality: Regression Discontinuity Evidence From The Minimum Age, American Economic Journal Applied Economics, 1(1), 164-182.

Cawley, J. ve Ruhm, C.J. (2012), The Economics of Risky Health Behaviors, In Mark V. Pauly, Thomas G. McGuire ve Pedro P. Barros (Eds.) Handbook of health economics, 2, (pp.95-200) Elsevier Publication.

Chaloupka, F.J., Grossman, M. ve Saffer, H. (2002), The effects of price on alcohol consumption and alcohol-related problems, Alcohol Research and Health, 26(1), 22-34.

Chaloupka, F.J, Saffer, H. ve Grossman, M. (1991), Alcohol control policies and motor vehicle fatalities, NBER Working Paper Series 3831.

Chaloupka, F.J, Tauras, J.A. ve Grossman, M. (2000), The Economics of Addiction”, In Prabhat Jha ve Frank J. Chaloupka (Eds.), Tobacco control in developing countries (pp. 107-129), Oxford University Press.

Charles, P. ve Perreira, K.M. (2007), Intimate partner violence during pregnancy and 1-year post-partum, Journal of Family Violence, 22, 609-619.

Cheng, C. C. ve Chu, H. (2017), Optimal policies for sin goods and health care: Tax or subsidy?, International Tax and Public Finance, 1-18.

Coker, A.L., Smith, P., McKeown, R.E. ve King, M. J. (2000), Frequency and correlates of intimate partner violence by type: physical, sexual, and psychological battering, American Journal of Public Health, 90(4), 553-559.

Cook, P.J. ve Moore, M.J. (2002), The economics of alcohol abuse and alcohol-control policies, Health Affairs, 21(2), 120-133.

Cook, P.J., Osterman, J. ve Sloan, F.A. (2005), Are alcohol excise taxes good for us? Short and long-term effects on mortality rates, NBER Working Paper Series, 11138.

Cook, P.J ve Tauchen, G. (1982), The effect of liqour taxes on heavy drinking, The Bell Journal of Economics, 13(2), 379-390.

Doll, R., Peto, R., Hall, E., Weatley K. ve Gray, R. (1994), Mortality in relation to consumption of alcohol: 13 years' observation on male British doctors, BMJ, 309, 911-918. 
Durance, C.P., Golden, S., Perreira, K. ve Cook, P. (2011), Taxing sin and saving lives: can alcohol taxation reduce female homicides?, Social Science \& Medicine, (73), 169-176.

FARE (2017), Stopping harm caused by alcohol, [fare.org.au/about] Erişim Tarihi: 11.12.2017.

Farrel, P. ve Fuchs, V.R. (1981), Schooling and health: the cigarette connection, NBER Working Paper Series, 768.

Gilman, S.E., Martin, L.T., Abrams, D.B., Kawachi, I., Kubzansky, L., Loucks, E.B., et al. (2008), Educational attainment and cigarette smoking: a causal association?, International Journal of Epidemiology, (37), 615-624.

Gruber, J. ve Koszegi, B. (2002), A theory of government of addictive bads: optimal tax levels and tax incidence for cigarette excise taxation, NBER Working Paper, 8777.

Hyman, D.N. (2010), Public finance: a contemporary application of theory to policy (10. Ed.), SouthWestern Cengage Learning, USA.

Kenkel, D. S. (1991), Health behavior, health knowledge, and schooling, Journal of Political Economy, 99(2), 287-305.

Lockwood, B. B. ve Taubinsky, D. (2017), Regressive sin taxes, NBER Working Paper Series, Paper no: $23085,1-63$.

Lorenzi, P. (2004), Sin taxes, Society, 41(3), 59-65.

Lyon, A.B. ve Schwab, R.M. (1995), Taxes in life-cycle framework: are sin taxes regressive?, The Review of Economics and Statistics, 77(3), 389-406.

Markowitz S. (2005), Alcohol, drugs and violent crime, International Review of Law and Economics, (25), 20-44.

Markowitz, S. ve Grossman, M. (1998), Alcohol regulation and domestic violence towards children, Contemporary Economic Policy, 16(3), 309-320.

Johnson, C.M. ve Meier, K.J. (1990), Wages of sin: taxing America's legal vices, The Western Political Quarterly, 43(3), 577-595.

Newman, S. Joel (2004), Slave tax as sin tax: 18th and 19th century perspectives, Wake Forest Law and Legal Theory Research Paper Series, 04-01.

Page, N., Sivarajasingam, V., Matthews, K., Heravi, S., Morgan, P. ve Shepherd, J. (2017), Preventing violence-related injures in England and Wales: a panel study examining the impact of on-trade and offtrade alcohol prices, Injury Prevention, 23(1), 33-39.

Ryder, H.E. ve Heal, G.M. (1973), Optimal growth with intertemporally dependent preferences, The Review of Economic Studies, 40(1), 1-31.

T.C. Başbakanlık Aile Araştırma Kurumu (1995), Aile içi şiddetin sebep ve sonuçları (Aralık 1993-Aralık 1994), Başbakanlık Aile Araştırma Başkanlığı Yayınları, Yayın No: 86.

Thornton, M. (2004), Harm reduction and sin taxes: why gary becker is wrong, In The dynamics of intervention: regulation and redistribution in the mixed economy, [Available online at: http://dx.doi.org/10.1016/S1529-2134(05)08014-2]. Retrived on March 9, 2016

Young, D. J. ve Bielinska-Kwapisz (2002), Alcohol taxes and beverage prices, National Tax Journal, $\mathrm{LV}(1), 57-73$.

Yuan, J.M., Ross, R.K, Gao, Y.T., Henderson B.E. ve Yu, M. C. (1997), Follow up study of moderate alcohol intake and mortality among middle aged men in Shanghai, China, British Medical Journal, 314(7073), 18-23. 